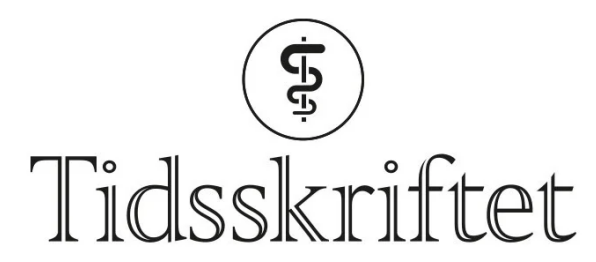

DEN NORSKE LEGEFORENING

\title{
Hvor godt virker legemidler for røykeslutt?
}

FRA ANDRE TIDSSKRIFTER

SOFIE PAUS

Tidsskriftet

\section{Bruk av både legemiddel og nikotinplaster i tre eller seks måneder ga like gode - eller dårlige - resultater som bruk av legemiddel alene.}

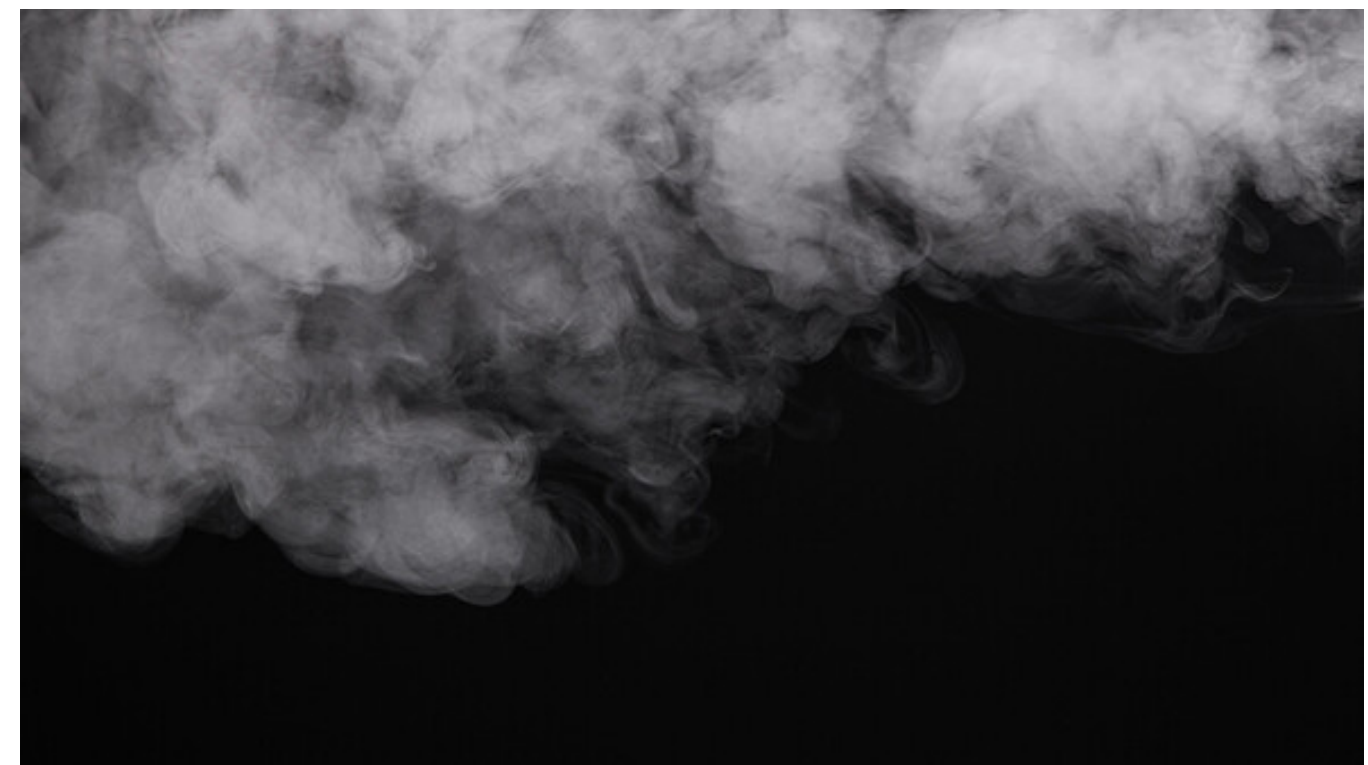

Illustrasjon:Chris_Tefme/iStock

I en dobbeltblind randomisert kontrollert studie ble flere enn 1200 personer som røykte mer enn fem sigaretter daglig, og som uttrykte et ønske om å slutte å røyke, delt i fire grupper: to som fikk tablettbehandling med vareniklin (en acetylkolinreseptorhemmer som binder seg til de samme reseptorene i hjernen som nikotin) i hhv. tre og seks måneder, og to som fikk både vareniklin og nikotinplaster i hhv. tre og seks måneder (1) $)$. Alle gruppene fikk i tillegg generelle råd om røykeslutt.

Etter ett år oppga deltakerne om de hadde vært røykfrie den siste uken. Dette ble kontrollert med måling av utåndet karbonmonoksid. Andelen som hadde klart å slutte å røyke, var rundt $25 \% \mathrm{i}$ alle gruppene. 
- Alle som ønsker å slutte å røyke, bør få tilbud om strukturert hjelp, og bør vurderes med tanke på bruk av legemidler, sier Jørn Ossum, som er spesialist i allmennmedisin og fastlege.

- Vareniklin kan være et effektivt middel til hjelp ved røykeslutt, og ulike kombinasjonsbehandlinger har vært lansert for ytterligere å øke suksessraten. Også varigheten av behandling har vært diskutert. Denne studien utgår fra et velrenommert senter for tobakksforskning i USA. En svakhet er at man manglet oppfølgningsdata for nesten en firedel av deltakerne ved 52 uker. Likevel kan vi slå fast at å kombinere vareniklin og nikotinerstatning neppe er hensiktsmessig, sier Ossum.

Ossum mener at effekten av 12 ukers behandling med vareniklin er best dokumentert, og opplyser at en studie har demonstrert ytterligere gevinst ved å forlenge behandlingen fra 12 til 24 uker, riktignok begrenset til røykere som hadde oppnådd røykfrihet ved 12 uker (2 $\underline{2})$.

- Bupropion er et annet middel med effekt ved røykeslutt, men dette midlet er dessverre trukket fra det norske markedet. Vi står derfor igjen med nikotinerstatninger og vareniklin. Leveransen av vareniklin har stanset en periode på grunn av produksjonsproblemer, sier Ossum, og minner om at frisklivssentralene er nyttige samarbeidspartnere i arbeidet med å hjelpe røykere til røykeslutt.

\section{REFERENCES}

1. Baker TB, Piper ME, Smith SS et al. Effects of combined varenicline with nicotine patch and of extended treatment duration on smoking cessation: a randomized clinical trial. JAMA 2021; 326:148593. [PubMed][CrossRef]

2. Tonstad S, Tønnesen P, Hajek P et al. Effect of maintenance therapy with varenicline on smoking cessation: a randomized controlled trial. JAMA 2006; 296: 64-71. [PubMed][CrossRef]

Publisert: 16. februar 2022. Tidsskr Nor Legeforen. DOI: 10.4045/tidsskr.21.09o8

(C) Tidsskrift for Den norske legeforening 2023. Lastet ned fra tidsskriftet.no 26. april 2023. 